\title{
FAKTOR-FAKTOR YANG MEMPENGARUHI KESIAPAN PENERAPAN STANDAR AKUNTANSI PEMERINTAHAN BERBASIS AKRUAL PADA PEMERINTAHAN DAERAH
}

\author{
Alfonsus Jantong, Nurkholis, Roekhudin \\ Universitas Brawijaya \\ Email: jantong.74@gmail.com
}

\begin{abstract}
The objective of this study is to analyze the readiness of local government in applying accrual-based governmental accounting standard. The effect of training, mentoring on human resource and the effect of human resource's quality, organizational commitment, and infrastructure on the readiness of the application of accrual-based governmental accounting standard are analyzed through positivist approach. The data is collected from 104 respondents through questionnaires distributed to SKPDs (local government agencies) working in accounting and to treasurers. The data is then analyzed using multiple regression method. The results show that training and mentoring positively affect the quality of human resource. The quality of human resource and infrastructure do not affect the readiness of accrual-based governmental accounting standard application. The quality of human resource, organizational commitment, and infrastructure simultaneously affect the readiness of accrual-based governmental accounting standard application. This research proves that local government of Manggarai, in terms of human resource and infrastructure, is not ready. The organizational commitment of Regency of Manggarai is ready to apply accrual-based governmental accounting standard.
\end{abstract}

Keywords: training, mentoring, quality of human resources, organizational commitment, infrastructure, and readiness for accrual based government accounting application

\begin{abstract}
Abstrak : Penelitian ini bertujuan untuk menganalisis kesiapan pemerintah daerah dalam penerapan standar akuntansi pemerintahan berbasis akrual. Analisis dilakukan terhadap pengaruh pelatihan, pendampingan terhadap kualitas sumber daya manusia dan pengaruh kualitas sumber daya manusia, komitmen organisasi, dan sarana prasarana terhadap kesiapan penerapan standar akuntansi pemerintah berbasis akrual, melalui pendekatan positivis. Pengumpulan data dilakukan menggunakan kuesioner, yang disebarkan kepada satuan kerja perangkat daerah (SKPD) yang menangani bidang akuntansi dan bendahara, sampel yang digunakan berjumlah 104 responden. Metode analisis data yang digunakan adalah regresi berganda. Hasil penelitian ini menunjukkan bahwa Pelatihan dan Pendampingan berpengaruh positif terhadap kualitas sumber daya manusia. Kualitas sumber daya manusia dan sarana prasarana tidak berpengaruh terhadap kesiapan penerapan standar akuntansi berbasis akrual, komitmen organisasi berpengaruh positif terhadap kesiapan penerapan standar akuntansi pemerintahan berbasis akrual. Secara bersama-sama kualitas sumber daya manusia, komitmen organisasi, dan sarana prasarana berpengaruh terhadap kesiapan penerapan standar akuntansi pemerintah berbasis akrual. Penelitian ini membuktikan bahwa kesiapan pemerintah daerah Kabupaten Manggarai dalam hal kualitas sumber daya manusia dan sarana prasarana belum siap. Komitmen organisasi pada Kabupaten Manggarai sangat siap untuk menerapkan standar akuntansi pemerintah berbasis akrual.
\end{abstract}

Kata Kunci: Pelatihan, Pendampingan, Kualitas Sumber Daya Manusia, Komitmen Organisasi, Sarana Prasarana, dan Kesiapan Penerapan Standar Akuntansi Pemerintah Berbasis Akrual. 


\section{PENDAHULUAN}

Perkembangan yang menarik pada sektor publik di Indonesia dewasa ini adalah semakin menguatnya tuntutan akuntabilitas publik oleh lembaga-lembaga publik, baik dipusat maupun di daerah. Akuntansi sektor publik memiliki peran yang sangat vital dalam memberikan informasi dan disclosure atas aktivitas dan kinerja finansial pemerintah daerah untuk memfasilitasi terciptanya transparansi dan akuntabilitas publik (Mardiasmo, 2004)

Tuntutan dilaksanakannya akuntabilitas publik mengharuskan pemerintah daerah untuk memperbaiki sistem pencatatan dan pelaporan. Perubahan sistem pencatatan tersebut adalah dari single entry menjadi double entry, dan perubahan dari sistem akuntansi berbasis kas menjadi akuntansi berbasis akrual. Perubahan tersebut merupakan bagian penting dari proses reformasi akuntansi sektor publik. Perubahan tersebut diharapkan dapat membantu meningkatkan transparansi dan memperbaiki efisiensi dan efektivitas sektor publik (Mardiasmo, 2004)

Dalam mewujudkan perubahan sistem akuntansi, pemerintah telah mengeluarkan paket undang-undang serta peraturan-peraturan yang berkaitan dengan perubahan tersebut diantaranya adalah Undang-Undang Nomor 17 Tahun 2003 tentang Keuangan Negara, UndangUndang Nomor 1 Tahun 2004 tentang Perbendaharaan Negara, Undang-Undang Nomor 15 Tahun 2004 tentang Pemeriksaan Pengelolaan dan Tanggung Jawab Keuangan Negara, Peraturan Pemerintah Nomor 24 Tahun 2005 tentang Standar Akuntansi Pemerintah yang telah diubah terakhir dengan Peraturan Pemerintah Nomor 71 Tahun 2010, Peraturan Pemerintah Nomor 8 Tahun 2006 tentang Pelaporan Keuangan \& Kinerja Instansi Pemerintahan, Peraturan Menteri Dalam Negeri Republik Indonesia Nomor 64 Tahun 2013 tentang Penerapan Standar Akuntansi Pemerintahan Berbasis Akrual pada Pemerintah Daerah. Hal yang menjadi pertanyaan adalah kesiapan pemerintah daerah dalam menerapkan SAP berbasis akrual.

Kesiapan ini dapat dinilai dari opini laporan keuangan pemerintah daerah (LKPD) yang diperoleh pemda, jika dengan penerapan SAP PP. 24 Tahun 2005 telah dapat memperoleh opini WTP, maka dapat diasumsikan kewajibanya untuk menerapkan sistem akuntansi berbasis akrual penuh tidak akan menghadapi kendala. Akan tetapi masih ada
LKPD kabupaten/kota yang memperoleh opini Tidak Memberikan Pendapat (TMP), salah satunya adalah Kabupaten Manggarai, selama Lima tahun. Kondisi ini menunjukkan bahwa kesiapan pemerintah daerah dalam penerapan standar akuntansi pemerintahan berbasis akrual yang secara simultan harus dilaksanakan pada tahun anggaran 2015 patut diperhatikan.

Akib (2010) menjelaskan bahwa untuk mendukung keberhasilan implementasi kebijakan perlu didasarkan pada tiga aspek; 1) tingkat kepatuhan birokrasi terhadap birokrasi di atasnya atau tingkat birokrasi, sebagaimana diatur dalam undang-undang, 2) adanya kelancaran rutinitas dan tidak adanya masalah, serta 3) pelaksanaan dan dampak (manfaat) yang dikehendaki dari semua program terarah. Ada empat faktor sebagai sumber masalah sekaligus prakondisi bagi keberhasilan proses implementasi, yakni komunikasi, sumber daya, sikap birokrasi atau pelaksana dan struktur organisasi dan termasuk tata aliran kerja biro. Empat faktor tersebut merupakan kriteria yang perlu ada dalam implementasi suatu kebijakan.

Christensen (2002) menemukan hambatan awal dalam proses implementasi penerapan akuntansi berbasis akrual baik eksternal maupun internal. Kambanei (2014) membuktikan bahwa tanpa mempertimbangkan faktor kondisi lokasi akan menjadi hambatan dalam mengimplementasikan akuntansi pemerintahan berbasis akrual. Athukorala (2003) mengungkapkan temuan dari negaranegara yang telah menerapkan akuntansi berbasis akrual. Hal yang menjadi kendala dalam mengimplementasikan adalah sumber daya manusia, kurangnya komitmen, dan reformasi manajemen keuangan pemerintah yang ambisius sering tidak sepenuhnya sesuai dengan manfaat yang dijanjikan, kapasitas (khususnya tenaga akuntansi), prioritas lain mungkin mendesak, korupsi dan kepentingan dapat merusak upaya ini, kegiatan donor bertentangan dapat mengurangi koherensi mereka, kelelahan reformasi, dan keterbatasan infrastruktur. Temuan ini sejalan dengan penelitian yang dilakukan oleh, Hepworth (2003), dan Winne (2000). Temuan ini menunjukkan bahwa penting persiapan awal untuk melakukan langkah-langkah yang strategis menghadapi suatu perubahan yang terjadi.

Ranuba, Pangemanan, dan Pinatik (2014) melakukan penelitian tentang analisis kesiapan penerapan standar akuntansi 
pemerintahan berbasis akrual PP No.71 Tahun 2010 menemukan bahwa sumber daya manusia, sarana prasarana, sosialisasi terkait dengan biaya masih kurang. Temuan ini sejalan dengan penelitian Sampel, Kalangi, dan Runtu (2014), Kusuma (2013), Arif (2013), dan Mongoloi (2013). Fadlan (2013) mengungkapkan beberapa kendala Pemda dalam menerapkan akuntansi akrual yaitu: belum adanya regulasi tentang kebijakan akuntansi pemerintah daerah berdasarkan basis akrual, kurangnya komitmen pemerintah daerah, kurangnya sosialisasi, masalah sumber daya manusia, masalah sarana prasarana, mutasi kepegawaian, dan belum siapnya menerima perubahan dikategorikan belum siap. Temuan ini sejalan dengan penelitian yang dilakukan oleh Binsar (2013).

Penelitian Aldiani (2010), Indah (2008), Nazier (2009), Winidyaningrum (2009), Damanik (2011), Ardiansyah (2013), Adventana, dan Kurniawan (2013), Sitepu (2010), Kusuma (2013), Arif (2013), Ramayanti (2012), dan Dora (2014) membuktikan bahwa sumber daya manusia, komitmen organisasi, dan sarana prasarana berpengaruh positif terhadap penerapan SAP akrual. Penelitian Sukardana, dan Mimba (2015) membuktikan bahwa kualitas sumber daya manusia berpengaruh positif terhadap kesiapan penerapan SAP akrual. Pramadani dan Fajrianthi (2012) membuktikan bahwa komitmen organisasi berpengaruh terhadap kesiapan untuk berubah. Ardiansyah (2013) menemukan komitmen organisasi tidak berpengaruh terhadap penerapan SAP akrual. Halen, dkk (2013), dan Kusuma (2013) memberikan bukti bahwa pelatihan dan pendampingan berpengaruh positif terhadap penerapan SAP akrual.

Temuan penelitian terdahulu yang mengungkapkan beberapa faktor yang menghambat keberhasilan penerapan akuntansi akrual pada sektor publik, menunjukkan bahwa betapa pentingnya kesiapan sebelum mengimplementasikan kebijakan. Temuan tersebut belum dapat mengklasifikasikan faktorfaktor yang merupakan kebutuhan dasar dalam mengimplementasi akuntansi berbasis akrual. Penelitian ini menekankan pada faktor kualitas sumber daya manusia, komitmen organisasi, dan sarana prasarana yang merupakan syarat yang paling mendasar untuk mempersiapkan penerapan SAP akrual.

Melihat pentingnya persiapan awal, peneliti termotivasi untuk melakukan penelitian terkait dengan faktor-faktor kesiapan antara lain;
Sumber daya manusia, komitmen organisasi, dan sarana prasarana. Penelitian ini menguji pengaruh pelatihan, pendampingan terhadap kualitas sumber daya manusia. Variabel tersebut merupakan penggabungan dari beberapa penelitian sebelumnya yaitu penelitian Halen, dkk (2013), dan Kusuma (2013), penggabungan tersebut bermaksud untuk mempredeksi kualitas sumber daya manusia dan dapat memberikan suatu jawab atau solusi atas permasalah kualitas sumber daya manusia yang dialami oleh pemerintah daerah.

Variabel dalam penelitian ini merupakan penggabungan dari beberapa penelitian sebelumnya yaitu penelitian yang dilakukan oleh Aldiani (2010), Ardiansyah (2013), Adventana dan Kurniawan (2013), dan Sukardana dan Mimba (2015). Penggabungan ini dimaksudkan untuk dapat memahami tentang kesiapan pemerintah daerah terhadap penerapan SAP akrual dan dapat memberikan jawaban atau solusi atas permasalahan fenomena penerapan SAP akrual yang dihadapi oleh pemerintah daerah.

\section{PENGEMBANGAN HIPOTESIS}

\section{Pengaruh pelatihan terhadap kualitas sumber daya manusia}

Pelatihan staf menjadi hal yang penting dalam mengimplementasikan kebijakan yang baru (Athukorala 2003). Pelatihan mempersiapkan peserta latihan untuk mengambil jalur tindakan tertentu dan membantu memperbaiki prestasi mereka dalam kegiatannya terutama mengenai pengertian dan keterampilan.Hal ini disebabkan karena karyawan tersebut biasanya direkrut dari lulusan-lulusan lembaga pendidikan diluar institusi yang bersangkutan (Lynto dan Paree dalam Halen, dkk. (2013)).

Untuk meningkatkan kualitas sumber daya manusia, maka upaya pendidikan dan pelatihan sangat diperlukan (Notoatmodjo, 2009). Penelitian Kusuma (2013) menemukan bahwa pelatihan staf berpengaruh positif terhadap penerapan akuntansi akrual. Berdasarkan uraian tersebut peneliti menduga:

H1a : Pelatihan standar akuntansi berbasis akrual berpengaruh positif terhadap kualitas sumber daya manusia

\section{Pengaruh pendampingan terhadap kualitas sumber daya manusia}

Pendampingan sebagai suatu strategi yang umum digunakan oleh pemerintah dan 
lembaga non profit dalam upaya meningkatkan mutu dan kualitas dari sumber daya manusia, sehingga mampu mengindentifikasikan dirinya sebagai bagian dari permasalahan yang dialami dan berupaya untuk mencari alternatif pemecahan masalah yang dihadapi.Kemampuan sumber daya manusia sangat dipengaruhi oleh keberdayaan dirinya sendiri. Oleh karena itu sangat dibutuhkan kegiatan pemberdayaan disetiap kegiatan pendampingan. Suharto (2005) dalam Lobo (2008) menguraikan bahwa pendampingan merupakan satu strategi yang sangat menentukan keberhasilan program pemberdayaan masyarakat. Dengan adanya pendampingan terhadap aparatur pemerintahan sehingga terjadinya proses perubahan kreatif yang diprakarsai oleh aparatur sendiri. Hal ini telah dibuktikan dalam penelitian Halen, dkk (2013). Berdasarkan uraian tersebut, maka dapat dirumuskan hipotesis penelitian sebagai berikut: $\mathrm{H} 1 \mathrm{~b}$ : Pendampingan berpengaruh positif terhadap kualitas sumber daya manusia

\section{Pengaruh kualitas sumber daya manusia terhadap kesiapan penerapan standar akuntansi berbasis akrual (SAP)}

Sebuah implementasi kebijakan publik dalam praktik, memerlukan kapasitas sumber daya yang memadai dari segi jumlah dan keahlian (Insani dalam Kusuma 2013).Kualitas sumber daya manusia memiliki peranan sentral dalam menentukan keberhasilan penerapan SAP berbasis akrual. Hal ini sejalan dengan Susilo dalam Aldiani (2010). Sumber daya manusia yang berlatar belakang pendidikan yang sesuai serta berpengalaman dalam bidang keuangan akan mampu menyelesaikan tugas-tugas serta beradaptasi dengan baik terhadap perubahan standar akuntansi. Penelitian Indah (2008), Nazier (2009), Aldiani (2010), Damanik (2011), Ardiansyah (2012), Rahmayanti (2012), Adventana dan Kurniawan (2013), Kusuma (2013), dan Arif (2013) memberikan bukti bahwa sumber daya manusia berpengaruh positif terhadap penerapan akuntansi akrual. Berdasarkan uraian tersebut peneliti menduga bahwa:

H2 : Kualitas sumber daya manusia berpengaruh positif terhadap kesiapan penerapan standar akuntansi pemerintahan berbasis akrual

Pengaruh komitmen organisasi terhadap kesiapan penerapan standar akuntansi pemerintahan berbasis akrual (SAP)
Komitmen organisasi merupakan dorongan dari dalam diri individu untuk melakukan sesuatu agar dapat menunjang keberhasilan organisasi dan lebih mengutamakan kepentingan organisasi (Luthans dalam Aldiani, 2010). Pegawai yang memiliki komitmen yang kuat akan bekerja dengan maksimal agar organisasi tempat mereka bekerja dapat mencapai keberhasilan. Jika pegawai berkeyakinan bahwa visi dan misi organisasi akan tercapai dengan sumbangsi mereka, situasi kerja yang bersinergi akan tercipta dan menyebabkan peningkatan kinerja. Hal ini dibuktikan dalam penelitian Indah (2008), Noch (2006), Aldiani (2010), Damanik (2011), Adventana dan Kurniawan (2013), Pratiwi, dkk (2013) tetapi tidak menurut Ardiansyah (2013). Berdasarkan uraian tersebut peneliti menduga hipotesa sebagai berikut:

H3. : Komitmen organisasi berpengaruh positif terhadap kesiapan penerapan standar akuntansi pemerintahan berbasis akrual

\section{Pengaruh Sarana Prasarana terhadap kesiapan penerapan standar akuntansi pemerintahan berbasis akrual (SAP)}

Sarana prasarana merupakan alat penunjang keberhasilan suatu proses upaya yang dilakukan di dalam pelayanan publik, karena apabila kedua hal ini tidak tersedia maka semua kegiatan yang dilakukan tidak akan dapat mencapai hasil yang diharapkan sesuai dengan rencana. Nugraihni, dkk (2008) menunjukkan bahwa sarana prasarana pada khususnya komputer, printer, dan sofware sangat berpengaruh terhadap keberhasilan penerapan standar akuntansi pemerintahan berbasis akrual. Temuan ini didukung oleh penelitian Indah, (2008), Aldiani (2010), Damanik (2011), Rahmayanti (2012), dan Kusuma (2013). Berdasarkan uraian tersebut, maka hipotesa sebagai berikut:

H4 : Sarana prasarana berpengaruh positif terhadap kesiapan penerapan standar akuntansi pemerintahan berbasis akrual

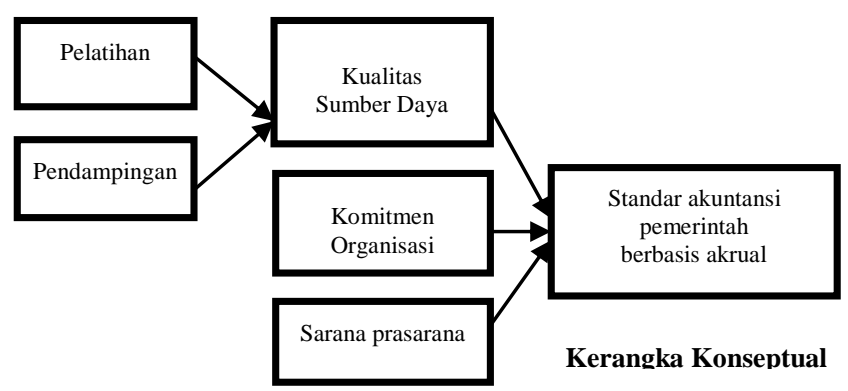




\section{METODE}

Penelitian ini termasuk pada jenis penelitian kuantitatif yang dikembangkan dalam pendekatan eksplanasi. Sedangkan untuk horizon waktu penelitian ini menggunakan cross sectional yakni penelitian atau pengumpulan data pada satu rentang waktu tertentu dan statistik inferensial berbentuk parametric, yaitu, teknik yang digunakan untuk menganalisis data sampel dan hasilnya diberlakukan untuk populasi (Sugiyono, 2014). Penelitian ini dilakukan di SKPD Pemerintah Daerah di Kabupaten Manggarai Propinsi Nusa Tenggara Timur (NTT). Populasi dari peneltian ini berjumlah 222 karyawan SKPD yang menempati bagian akuntansi dan bendahara yang tersebar di tiga kabupaten, dengan menggunakan formula Slovin dalam penentuan sampelnya, maka jumlah sampel dalam penelitian ini sebanyak 142 responden. Untuk pengukuran data, penelitian ini menggunakan skala pengukuran interval yang diukur berdasarkan teknik skala likert dengan skor antara 1-6. Dengan ketentuan sebagai berikut: skor 6 (SS=Sangat Setuju), skor 5 (S=Setuju), skor 4 (AS=Agak Setuju), skor 3 (ATS=Agak Tidak Setuju), skor 2 (TS=Tidak Setuju), skor 1 (STS= Sangat Tidak Setuju).

Sebelum dilakukan penyebaran kuisioner ke responden yang sudah ditentukan, peneliti melakukan pretest instrumen yang disebarkan ke satuan kerja perangkat daerah (SKPD) Manggarai Timur sebanyak 31 responden (Dinas Pendapatan Pengelolaan Keuangan dan Aset Daerah dan Dinas Perindustrian, Perdagangan, dan Koperasi). Uji validitas yang digunakan dalam penelitian ini menggunakan confirmatory factor analysis (CFA) dengan asumsi jika indikator merupakan indikator dari suatu konstruk maka dengan sendirinya akan mengelompokan menjadi satu dengan faktor loading yang tinggi (Ghozali 2011). Sedangkan untuk uji reliabilitas digunakan Cronbach Alpha dengan rumus:

$$
\mathrm{r} i=\frac{\mathrm{k}}{(\mathrm{k}-1)}\left\{1-\frac{\sum \mathrm{s}_{\mathrm{i}}^{2}}{\mathrm{~s}_{\mathrm{t}}^{2}}\right\}
$$

dimana:

$$
\begin{aligned}
\mathrm{r}_{\mathrm{i}}= & \text { reliabilitas instrumen } \\
\mathrm{k}= & \text { mean kuadrat antara subyek atau } \\
& \text { banyaknya butir pertanyaan/ } \\
& \text { banyaknya soal } \\
\mathrm{S}_{\mathrm{i}}= & \text { mean kuadrat kesalahan } \\
\mathrm{s}_{\mathrm{t}}= & \text { varian total }
\end{aligned}
$$

Analisis data yang digunakan adalah analisis regresi berganda dengan bantuan perhitungan melalui program SPSS. Tujuan analisis regresi adalah untuk mengetahui ada tidaknya pengaruh signifikan antara satu atau lebih variabel bebas terhadap variabel terikatnya baik secara parsial atau simultan (Yudiaatmaja, 2013). Rumus yang digunakan dalam analisis ini:

1. Persamaan Regresi: $\dot{Y}=a+b X$

Dimana:

$\dot{\mathrm{Y}}=$ subjek variabel terikat yang diproyeksikan

$\mathrm{X}=$ Variabel bebas yang mempunyai nilai tertentu untuk diprediksikan

$$
\begin{aligned}
\mathrm{a}= & \text { Nilai konstanta harga } \mathrm{Y} \text { jika } \mathrm{X}=0 \\
\mathrm{~b}= & \text { nilai arah sebagai penentu ramalan } \\
& \text { (prediksi) yang menunjukkan nilai } \\
& \text { peningkatan }(+ \text { ) atau nilai penurunan } \\
& (-) \text { variabel } \mathrm{Y}
\end{aligned}
$$

2. Persamaan regresi ganda : $\dot{Y}=a+b_{1} X_{1 a}+$ $\mathrm{b}_{2} \mathrm{X}_{\mathrm{b}}+\mathrm{e}$ Model 1

Persamaan regresi ganda: $\dot{\mathrm{Y}}=\mathrm{a}+\mathrm{b}_{1} \mathrm{X}_{1}+$ $\mathrm{b}_{2} \mathrm{X}_{2}+\mathrm{b}_{3} \mathrm{X}_{3}+\mathrm{e}$ Model 2

Selanjutnya, untuk mengetahui status keabsahan data, peneltiian ini menggunalan persamaan yang memenuhi kaidah Best Linear Unbias Estimator (BLUE). Untuk memenuhi kaidah tersebut, maka data yang digunakan diuji asumsi klasik. Uji asumsi klasik mencakup uji normalitas, uji multikolinearitas, dan uji linearitas (Ghozali, 2011).

\section{HASIL PENELITIAN}

Berdasarkan data yang didapat dilapangan, sebelum dilakukan pengujian hipotesis, peneliti melakukan uji validitas dan reliabilitas instrument penelitian. Dengan menggunakan bantuan SPSS, hasil yang didapat positif. Semua instrument dari masing-masing variabel disimpulkan valid dan reliable sesuai dengan yang telah ditentukan. Pada tahap selanjutnya, peneliti melakukan uji asumsi klasik untuk mendapatkan gambaran persamaan dan model konstruk yang sesuai dengan standar.

Berdasarkan hasil uji asumsi klasik, dapat dismpulkan bahwa dari semua jenis pengujian sudah sesuai dengan ketentuan. Pengujian uji normalitas, nilai signifikansi residual regresi yang terbentuk lebih besar dari taraf nyata $5 \%$ baik pada model regresi 1 maupun model regresi 2, sehingga dapat dikatakan bahwa asumsi normalitas tersebut terpenuhi. Sedangkan untuk uji 
multikolinieritas, menunjukkan bahwa model 1 maupun model 2 memiliki nilai VIF $<10$ atau nilai tolerance $>0,1$, sehingga dapat dikatakan tidak terdapat gejala multikolinearitas antara variabel bebas. Sementara itu, untuk uji linieritas menunjukkan bahwa variabel bebas berhubungan linier terhadap variabel terikat $\mathrm{Y}$. Pada model 1 pelatihan dan pendampingan berhubungan linier dengan kualitas sumber daya manusia. Pada model 2, variabel kualitas sumber daya manusia, komitmen organisasi dan sarana prasarana berhubungan linier dengan variabel terikat. Atau dengan kata lain asumsi linieritas dalam regresi telah terpenuhi.

Selanjutnya, peneliti melakukan analisis data dengan berdasarkan analisis regresi berganda. Analisis dilakukan dalam dua tahap yaitu pelatihan (X1a) dan pendampingan (X1b) terhadap kualitas sumber daya manusia (X1) yang disebut sebagai model satu. Kualitas sumber daya manusia (X1), komitmen organisasi (X2), dan sarana prasarana (X3) terhadap kesiapan penerapan standar akuntansi pemerintahan berbasis akrual (Y) sebagai model kedua. Secara ringkas hasil analisis regresi berganda terdapat dalam tabel 1 .

Tabel 1: Ringkasan Hasil Uji Regresi

\begin{tabular}{|c|c|c|c|c|c|}
\hline \multirow[t]{2}{*}{ Variabel } & \multicolumn{2}{|c|}{$\begin{array}{c}\text { Model I } \\
\text { KSDM (X1) =PL } \\
\text { (X1a) + PD (X1b) }\end{array}$} & \multirow[t]{2}{*}{ Variabel } & \multicolumn{2}{|c|}{$\begin{array}{c}\text { Model II } \\
\text { KPPA (Y) = KSDM } \\
(\mathbf{X 1})+\mathrm{KO}(\mathbf{X} 2)+\text { SP(X3 }\end{array}$} \\
\hline & Koefisien & Keterangan & & Koefisien & Keterangan \\
\hline Konstanta & 0,000 & & Konstanta & 0,000 & \\
\hline Pelatihan & $\begin{array}{c}0,318^{*} \\
*\end{array}$ & $\begin{array}{c}\text { Ada } \\
\text { pengaruh }\end{array}$ & $\begin{array}{l}\text { Kualitas } \\
\text { sumber } \\
\text { daya } \\
\text { manusia }\end{array}$ & $-0,211$ & $\begin{array}{l}\text { Tidak ada } \\
\text { pengaruh }\end{array}$ \\
\hline Nilai t & 2,443 & & Nilai t & $-0,795$ & \\
\hline Pendampingan & $\begin{array}{c}0,339 * \\
*\end{array}$ & $\begin{array}{c}\text { Ada } \\
\text { pengaruh }\end{array}$ & $\begin{array}{l}\text { Komitmen } \\
\text { organisasi }\end{array}$ & 0,649 & $\begin{array}{c}\text { Ada } \\
\text { pengaruh }\end{array}$ \\
\hline Nilai t & 2,598 & & Nilai t & 2,334 & \\
\hline F & 32,160 & & $\begin{array}{l}\text { Sarana } \\
\text { prasarana }\end{array}$ & 0,187 & $\begin{array}{l}\text { Tidak ada } \\
\text { pengaruh }\end{array}$ \\
\hline $\mathrm{R}^{2}$ & 0,389 & & Nilai t & 0,992 & \\
\hline Adjuste $\mathrm{R}^{2}$ & 0,377 & & $\mathrm{~F}$ & 4,734 & \\
\hline \multirow[t]{3}{*}{$\mathrm{R}$} & 0,624 & & $\mathrm{R}^{2}$ & 0,124 & \\
\hline & & & $\begin{array}{l}\text { Adjuste } \\
\mathrm{R}^{2}\end{array}$ & 0,098 & \\
\hline & & & $\mathrm{R}$ & 0,353 & \\
\hline
\end{tabular}

Sumeber: Data Primer (2016)

Pelatihan dan Pendampingan terhadap
Kualitas Sumber Daya Manusia

Berdasarkan tabel 1 dapat diketahui bahwa persamaan regresi sebagai berikut: $\mathrm{X} 1=0,000+0,318 \mathrm{X} 1 \mathrm{a}+0,339 \mathrm{X} 1 \mathrm{~b}$

Kualitas sumber daya manusia $=0,000$ $+0,318$ pelatihan $+0,339$ pendampingan
Pada tabel 1 dibagian uji $\mathrm{F}$ diperoleh nilai $F$ 32,160 dengan signifikan 0,000 dan koefisien korelasi yang dihasilkan sebesar 0,624 yang berarti terdapat hubungan yang kuat antara pelatihan (X1a) dan pendampingan (X1b) terhadap kualitas sumber daya manusia. Koefisien determin $\left(\mathrm{R}^{2}\right)$ yang dihasilkan sebesar 0,377 yang berarti bahwa kualitas sumber daya manusia (X1) dipengaruhi oleh pelatihan (X1a) dan pendampingan (X1b) sebesar 37,7\%, sedangkan sisanya yaitu $62,3 \%$ dipengaruhi oleh faktor lain selain pelatihan dan pendampingan.

Kualitas Sumber Daya Manusia, Komitmen Organisasi, dan Sarana prasarana terhadap Kesiapan Penerapan Standar Akuntansi Pemerintahan Berbasis Akrual

Berdasarkan tabel 1 dapat diketahui bahwa persamaan regresi sebagai berikut:

$$
\mathrm{Y}=0,000-0,0211 \mathrm{X} 1+0,649 \mathrm{X} 2+
$$
0,187X3

Kesiapan penerapan standar akuntansi pemerintahan berbasis akrual $=0,000-0,211$ kualitas sumber daya manusia $+0,649$ komitmen organisasi $+0,187$ sarana prasarana.

Pada tabel 1, pada bagian uji $\mathrm{F}$ diperoleh nilai $F \quad 4,734$ dengan signifikan 0,004 dan koefisien korelasi yang dihasilkan 0,353 yang berarti terdapat hubungan yang kuat antara kualitas sumber daya manusia (X1), komitmen organisasi (X2), dan sarana prasarana (X3) terhadap kesiapan penerapan standar akuntansi pemerintahan berbasis akrual. Koefisien determin $\left(\mathrm{R}^{2}\right)$ yang dihasilkan sebesar 0,098 yang berarti bahwa kesiapan penerapan standar akuntansi pemerintahan berbasis akrual (Y) dipengaruhi oleh kualitas sumber daya manusia (X1), komitmen organisasi (X2), dan sarana prasarana (X3) sebesar 9,8\%, sedangkan sisanya yaitu 90,2\% dipengaruhi oleh faktor lain selain kualitas sumber daya manusia, komitmen organisasi, dan sarana prasarana.

\section{Pengujian Hipotesis}

Penelitian ini mengajukan sebanyak lima hipotesis. Hasil penelitian menunjukkan bahwa pertama, berdasarkan hasil analisis data, dengan menggunakan uji $\mathrm{t}$ untuk hubungan variabel pelatihan (X1a) terhadap kualitas sumber daya manusia (X1) menunjukkan hasil sebesar 0,016 dan signifikansi pada 0,05 . Hal ini mengindikasikan bahwa pengaruh pelatihan terhadap kualitas sumber daya manusia signifikan, artinya pelatihan standar akuntansi berbasis akrual mampu meningkatkan kualitas 
sumber daya manusia. Hal tersebut bermakna bahwa H1a diterima.

Kedua, dengan menggunakan uji t, hubungan antara pendampingan (X1b) dan kualitas sumber daya manusia (X1) menunjukkan hasil sebesar 0,011 dan signifikan pada 0,05. Hasil ini mengindikasikan bahwa pengaruh pendampingan terhadap kualitas sumber daya manusia signifikan, artinya pendampingan mampu meningkatkan kualitas sumber daya manusia. Dengan demikian, $\mathrm{H} 1 \mathrm{~b}$ juga diterima. Ketiga, hubungan antara kualitas sumber daya manusia (X1) dan kesiapan penerapan standar akuntansi pemerintahan berbasis akrual (Y), nilai uji t adalah sebesar 0,429 dan tidak signifikan pada 0,05 . Hasil ini mengindikasikan bahwa pengaruh kualitas sumber daya manusia terhadap kesiapan penerapan standar akuntansi pemerintahan tidak signifikan, artinya kesiapan pemerintah daerah dalam hal kualitas sumber daya manusia belum siap. Dengan demikian H2 ditolak.

Keempat, melihat nilai uji $\mathrm{t}$ dari hubungan antara komitmen organisasi (X2) dan kesiapan penerapan standar akuntansi pemerintahan berbasis akrual (Y), hasil yang didapat adalah sebesar 0,022 dan signifikan pada 0,05 mengindikasikan bahwa pengaruh komitmen organisasi terhadap kesiapan penerapan standar akuntansi pemerintahan berbasis akrual signifikan, artinya komitmen organisasi mampu meningkatkan kesiapan penerapan standar akuntansi pemerintahan berbasis akrual. Dengan demikian H3 diterima. Kelima, nilai uji t hubungan antara sarana prasarana (X3) dan kesiapan penerapan standar akuntansi berbasis akrual (Y) adalah sebesar 0,324 dan tidak signifikan pada 0,05 mengindikasikan bahwa pengaruh sarana prasarana terhadap kesiapan penerapan standar akuntansi pemerintahan berbasis akrual tidak signifikan, artinya kesiapan pemerintah daerah dalam hal sarana prasarana belum siap dalam menerapakan standar akuntansi pemerintahan berbasis akrual. Dengan demikian H4 ditolak.

\section{PEMBAHASAN}

Berdasarkan hasil pengujian lima hipotesis dalam penelitian ini terdapat tiga hipotesis yang diterima $(\mathrm{H} 1 \mathrm{a}, \mathrm{H} 1 \mathrm{~b}$, dan $\mathrm{H} 2)$ dan dua hipotesis yang ditolak (H1) dan (H3). Penelitian ini berhasil membuktikan bahwa pelatihan dan pendampingan berpengaruh terhadap kualitas sumber daya manusia, selain itu komitmen organisasi berpengaruh terhadap kesiapan penerapan standar akuntansi berbasis akrual. Sebaliknya kualitas sumber daya manusia dan sarana prasarana tidak berpengaruh terhadap kesiapan penerapan standar akuntansi berbasis akrual. Sub pokok bahasan berikut ini akan dibahas setiap hipotesis penelitian.

\section{Pengaruh Pelatihan Terhadap Kualitas Sumber Daya Manusia}

Hasil pengujian hipotesis menunjukkan bahwa pelatihan berpengaruh terhadap kualitas sumber daya manusia. Hal ini menunjukkan bahwa pelatihan yang diberikan terhadap karyawan atau staf akan meningkatkan keterampilan, pengetahuan dan pemahaman mereka terhadap pekerjaan yang mereka lakukan.

Temuan ini sejalan dengan studi yang dilakukan oleh Kusuma (2013), Halen,dkk (2013) dan Nugraini (2008) yang menyatakan bahwa pelatihan staf keuangan sangat berpengaruh lansung terhadap keberhasilan penerapan standar akuntansi berbasis akrual. Hasil tersebut juga dapat mendukung teori yang dikembangkan oleh Notoatmodjo (2009) yang menyatakan bahwa pelatihan merupakan bagian dari suatu proses pendidikan, yang tujuannya untuk meningkatkan kemampuan atau keterampilan khusus seseorang atau kelompok orang. Temuan ini juga mendukung teori yang diungkapkan oleh Wibowo (2014) yang mengungkapkan pelatihan sebagai investasi organisasi yang penting dalam sumber daya manusia. Hasil penelitian ini menunjukkan bahwa semakin seringnya karyawan atau staf mengikuti pelatihan akan semakin meningkat keterampilan mereka dalam melakukan pekerjaannya.

\section{Pengaruh Pendampingan terhadap Kualitas Sumber Daya Manusia}

Pendampingan sebagai suatu strategi yang umum digunakan oleh pemerintah dan lembaga non profit dalam upaya meningkatkan mutu dan kualitas dari sumber daya manusia, sehingga mampu mengidentifikasikan dirinya sebagai bagian dari permasalahan yang dialami dan berupaya untuk mencari alternatif pemecahan masalah yang dihadapi. Hasil pengujian hipotesis dalam penelitian ini menunjukkan bahwa pendampingan berpengaruh positif dan signifikan terhadap kualitas sumber daya manusia. Semakin sering dilakukan pendampingan terhadap pegawai atau karyawan akan semakin meningkatkan 
keterampilan dan pengetahuan dalam melakukan pekerjaan serta semakin mudah untuk menyelesaikan permasalahannya. Temuan ini sejalan dengan konsep yang diungkapkan oleh Suharto (2005) dalam Lobo (2008) dengan mengatakan bahwa dengan adanya pendampingan terhadap aparatur pemerintahan akan terjadinya proses perubahan kreatif yang diprakarsai oleh aparatur sendiri. Temuan ini mendukung penelitian Halen, dkk (2013) yang menghubungkan pengaruh langsung pendampingan terhadap keberhasilan penerapan akuntansi berbasis akrual yang menemukan bahwa pendampingan sangat berpengaruh terhadap penerapan akuntansi berbasis akrual.

\section{Pengaruh Kualitas Sumber Daya Manusia Terhadap Kesiapan Penerapan Standar Akuntansi Berbasis Akrual}

Implementasi kebijakan publik dalam praktik, memerlukan kapasitas sumber daya yang memadai dari segi jumlah dan keahlian. Sumber daya manusia memiliki peranan sentral dalam menentukan keberhasilan penerapan standar akuntansi pemerintah berbasis akrual. Hasil pengujian hipotesis dalam penelitian ini menunjukkan bahwa kualitas sumber daya manusia tidak berpengaruh signifikan terhadap kesiapan penerapan standar akuntansi berbasis akrual. Temuan ini menunjukkan bahwa kualitas sumber daya manusia pada Pemerintah Daerah Kabupaten Manggarai belum siap. Temuan ini sejalan dengan penelitian yang dilakukan Ranuba, Pangemanan, dan Pinantik (2014) yang menemukan sumber daya manusia masih kurang, yang mengkategorikan belum siap. Temuan ini juga sejalan dengan penelitian yang dilakukan Sampel, Kalangi, dan Runtu (2014), Kusuma (2013), Arif (2013), Mongoloi (2013) dan Fadlan (2013). Temuan ini sangat berbeda dengan penelitian Aldiani (2010), Indah (2008), Nazier (2009), Ramayanti (2012), Ardiansyah (2013), Andventana dan Kurniawan (2013), Sukadana dan Mimba (2015) yang membuktikan bahwa sumber daya manusia berpengaruh positif terhadap kesiapan penerapan standar akuntansi berbasis akrual.

Terdapat beberapa penyebab yang tidak mempengaruhi kesiapan penerapan standar akuntansi berbasis akrual antara lain; kebanyakan responden hanya sekali mengikuti pelatihan terhadap akuntansi berbasis akrual, dan penempatan pegawai yang bukan latar belakang akuntansi menjadi dominan.
Pengaruh Komitmen Organisasi Terhadap Kesiapan Penerapan Standar Akuntansi Berbasis Akrual

Pegawai yang memiliki komitmen yang kuat akan bekerja dengan maksimal agar organisasi tempat mereka bekerja dapat mencapai keberhasilan. Jika pegawai yang berkeyakinan bahwa visi dan misi organisasi akan tercapai dengan sumbangsi mereka, situasi kerja yang bersinergis akan tercipta dan menyebabkan peningkatan kesiapan terhadap perubahan. Hasil pengujian hipotesis dalam penelitian ini menunjukkan bahwa komitmen organisasi berpengaruh positif dan signifikan terhadap kesiapan penerapan standar akuntansi berbasis akrual. Temuan ini sejalan dengan penelitian Aldiani (2010), Indah (2008), Noch (2006), Damanik (2011), Pratiwi, dkk (2013), Adventana dan Kurniawan (2013), dan Dora (2014) yang menemukan bahwa komitmen organisasi berpengaruh positif dan signifikan terhadap kesiapan penerapan standar akuntansi berbasis akrual. Hasil penelitian ini berbeda dengan penelitian Ardiansyah (2012) yang menemukan bahwa komitmen organisasi tidak berpengaruh terhadap kesiapan penerapan standar akuntansi berbasis akrual.

\section{Pengaruh Sarana Prasarana Terhadap Kesiapan Penerapan Standar Akuntasi Berbasis Akrual}

Ketersediaan sarana prasarana pada dasarnya memberikan kemudahan dalam proses pelaksanaan pekerjaan, sehingga dapat meningkatkan produktivitas serta menimbulkan rasa kenyamanan bagi orang-orang yang melaksanakan aktivitas yang menimbulkan rasa puas pada orang-orang yang berkepentingan. Hasil pengujian hipotesis dalam penelitian ini menunjukkan bahwa sarana prasarana tidak berpengaruh terhadap kesiapan penerapan standar akuntansi berbasis akrual. Temuan ini mendukung penelitian sebelumnya yang dilakukan oleh Ranuba,dkk (2013), Sampel, dkk (2014), Arif (2013), Mongoloi (2013), dan Fadlan (2013) yang mengungkapkan bahwa ketersedian sarana prasarana masih kurang dalam menerapkan standar akuntansi pemerintahan berbasis akrual.Temuan ini berbeda dengan penelitian yang dilakukan oleh Aldiani (2010), Nugraheni (2008), Damanik (2011), Rahmawati (2012), Kusuma (2013), dan Dora (2014) yang menemukan bahwa sarana prasarana berpengaruh positif terhadap 
penerapan standar akuntansi pemerintahan berbasis akrual.

Temuan ini menunjukkan bahwa kesiapan Pemerintah Daerah Kabupaten Manggarai dalam mengimplementasikan standar akuntansi berbasis akrual dapat dikatakan belum siap dari segi ketersediaan sarana prasarana. Ketersedian sarana prasarana dapat menunjang kegiatan pemerintah dalam mewujudkan tujuan yang hendak dicapai.

\section{Pengaruh Pelatihan dan Pendampingan Terhadap Kualitas Sumber Daya Manusia}

Keberhasilan suatu negara sangat ditentukan oleh kualitas sumber daya manusia. Untuk meningkatkan kualitas sumber daya manusia pendidikan merupakan sarana untuk memberikan pengetahuan dan keterampilan baik secara formal maupun non formal. Pelatihan dan pendampingan merupakan bagian dari proses peningkatan kualitas sumber daya manusia. Sebagaimana teori yang diungkapkan oleh Notoatmodjo (2009) menyatakan bahwa pelatihan merupakan bagian dari suatu proses pendidikan yang tujuannya untuk meningkatkan kemampuan dan keterampilan khusus seseorang atau kelompok orang. Pendampingan merupakan bagian dari proses perubahan yang kreatif untuk meningkatkan mutu dan kualitas sumber daya manusia dalam menghadapi permasalahan yang dialami (Suharto, (2005) dalam Lobo, (2008)). Hasil pengujian dalam penelitian ini membuktikan bahwa pelatihan dan pendampingan memiliki hubungan yang kuat sebesar 0,624 dan secara bersama-sama memberikan kontribusi terhadap kualitas sumber daya manusia sebesar $37,7 \%$. Temuan ini menunjukkan bahwa pelatihan dan pendampingan sangat efektif untuk meningkatkan keterampilan staf atau karyawan.

\section{Pengaruh Kualitas Sumber Daya Manusia, Komitmen organisasi, dan Sarana prasarana Terhadap Kesiapan Penerapan Standar Akuntansi Pemerintahan Berbasis Akrual}

Hasil pengujian dalam penelitian ini membuktikan bahwa kualitas sumber daya manusia dan sarana prasarana tidak berpengaruh terhadap kesiapan penerapan standar akuntansi pemerintahan berbasis akrual. Komitmen organisasi berpengaruh positif dan signifikan terhadap kesiapan penerapan standar akuntansi pemerintahan berbasis akrual. Temuan penelitian ini menunjukkan bahwa kualitas sumber daya manusia, sarana prasarana, dan komitmen organisasi terdapat hubungan yang kuat terhadap kesiapan penerapan standar akuntansi pemerintahan berbasis akrual sebesar 0,353 . Kualitas sumber daya manusia, sarana prasarana dan komitmen organisasi secara bersama-sama memberikan kontribusi terhadap keberhasilan penerapan standar akuntansi pemerintahan berbasis akrual sebesar 9,8\%. Temuan ini menunjukkan bahwa kualitas sumber daya manusia dan sarana prasarana tidak akan berpengaruh tanpa memiliki komitmen yang kuat dari organisasi yang akan mendukung kegiatan mereka dalam menghadapi kesiapan penerapan SAP akrual. Temuan ini juga mendukung penelitian yang dilakukan oleh Aldiani (2010), Adventana dan Kurniawan (2013), Ardiansyah (2013), dan Dora (2014) yang membuktikan bahwa secara bersama-sama kualitas sumber daya manusia, komitmen organisasi dan sarana prasarana berpengaruh terhadap kesiapan penerapan standar akuntansi pemerintahan berbasis akrual.

Penelitian ini menunjukkan bahwa pelatihan dan pendampingan memiliki pengaruh yang kuat dan signifikan terhadap kualitas sumber daya manusia. Komitmen organisasi juga menunjukkan pengaruh yang kuat dan signifikan terhadap kesiapan penerapan standar akuntansi pemerintah berbasis akrual. Hal ini menunjukkan bahwa kontribusi dari pelatihan dan pendampingan menjadi penting untuk diperhatikan. Pelatihan dan pendampingan dapat dipandang sebagai investasi bagi organisasi dalam jangka pendek. Untuk memenuhi kebutuhan jangka pendeknya pendekatan pelatihan dan pendampingan menjadi pilihan yang tepat, guna meningkatkan kemampuan dan keterampilan karyawan atau staf yang sudah menduduki atau yang akan menempati posisi dan kedudukan yang baru atau yang dihadapkan pada kondisi tertentu, seperti penerapan program yang baru.

Komitmen organisasi dipercaya akan memunculkan kontribusi positif dalam diri karyawan atau staf. Komitmen organisasi yang tinggi akan menggerakan usaha lebih dalam menghadapi suatu perubahan guna membangun sikap yang positif terhadap situasi dan kondisi yang dihadapi oleh organisasi. Keterlibatan dan pemberdayan terhadap karyawan akan meningkatkan komitmen terhadap organisasi, serta menumbuhkan kemampuan dan kesiapan mereka dalam menghadapi perubahan dalam organisasi tersebut. Temuan peneliti menunjukkan bahwa komitmen organisasi 
menjadi penting dalam menghadapi perubahan dalam organisasi tersebut.

\section{KESIMPULAN}

Pelatihan dan pendampingan mempunyai pengaruh positif dan signifikan terhadap kualitas sumber daya manusia. Hal ini menunjukkan bahwa semakin sering staf atau karyawan mengikuti pelatihan dan pendampingan akan meningkatkan keterampilan dan membantu mereka dalam melaksanakan pekerjaan mereka. Penelitian ini juga berhasil membuktikan bahwa komitmen organisasi sangat berpengaruh positif dan signifikan terhadap kesiapan penerapan standar akuntansi pemerintah berbasis akrual. Namun demikian. Kualitas sumber daya manusia dan sarana prasarana tidak mempunyai pengaruh terhadap kesiapan penerapan standar akuntansi berbasis akrual. Selanjutnya, kontribusi kualitas sumber daya manusia, komitmen organisasi, dan sarana prasarana secara bersama-sama berpengaruh terhadap kesiapan penerapan standar akuntansi berbasis akrual. Hasil studi ini menunjukkan bahwa kualitas sumber daya manusia dan sarana prasarana pada Pemerintah Daerah Kabupaten Manggarai belum siap. Komitmen organisasi memiliki kontribusi yang paling berpengaruh terhadap kesiapan penerapan standar akuntansi berbasis akrual. Temuan ini menunjukkan bahwa SKPD Pemerintah Daerah Kabupaten Manggarai memiliki Komitmen yang kuat terhadap Penerapan Standar Akuntansi Pemerintahan Berbasis Akrual.

Penelitian ini telah diupayakan secara sistematis dan seakurat mungkin, namun masih terdapat keterbatasan. Adapun yang menjadi keterbatasan pada penelitian ini, yakni: pertama, nilai realibilitas dari variabel pelatihan, pendampingan, dan kualitas sumber daya manusia mendekati batas minimum yang dipersyaratkan. Kedua, responden dalam penelitian ini didominasi oleh mereka yang mengikuti pelatihan dan pendampingan hanya sekali, sehingga tidak menutup kemungkinan terjadi bias. Ketiga, kemungkinan ada variabel lain yang sangat penting tetapi tidak dimasukkan dalam penelitian ini berkaitan dengan kesiapan penerapan standar akuntansi berbasis akrual, seperti komitmen pimpinan.

Penelitian yang akan datang diharapkan mampu memperbaiki konstruk yang mengukur variabel pelatihan, pendampingan, dan kualitas sumber daya manusia. Ketiga variabel tersebut telah memenuhi nilai reliabilitas, namun nilainya mendekati batas minimum yang dipersyaratkan, sehingga nilai reliabilitasnya dapat ditingkatkan. Kesiapan penerapan standar akuntansi berbasis akrual sangat ditentukan oleh komitmen pimpinan, oleh sebab itu peneliti dimasa datang diharapkan mengeksplorasi komitmen pimpinan dan mengetahui pengaruhnya terhadap kesiapan penerapan standar akuntansi berbasis akrual.

\section{DAFTAR PUSTAKA}

Adventana, G. A., dan Kurniawan, H. 2013. Analisis Faktor-faktor yang Mempengaruhi Pemerintah Provinsi DIY dalam Implementasi SAP Berbasis Akrual Menurut PP No.71 Tahun 2010. Jurnal Fakultas Ekonomi Atma jaya Yogyakarta.Volume 4. No.1 April 2014

Akib.H. (2010). "Implementasi Kebijakan: Apa, Mengapa dan Bagaimana." Jurnal Administrasi Publik. Volume I No 1. (http://haedarakib.files.wordpress.com/201 1/03/implementasi-kebijakan. pdf). [9Januari 2016]

Aldiani. 2010. Faktor-faktor Pendukung Keberhasilan Penerapan PP No.24 Tahun 2005 pada Pemerintah Kabupaten Labuan Batu. Skripsi Fakultas Ekonomi Universitas Medan

Arif, M.M. 2013. Analisis Kesiapan Pemerintah Daerah Dalam Penerapan Standar Akuntansi Pemerintah Berbasis Akrual (Studi pada Pemerintah Daerah Kabupaten Bondowoso). Skripsi Fakultas Ekonomi Universitas Jember Jurusan Akuntansi

Athukorala, S.L. 2003. Accrual Budgeting And Accounting In Government And Its relevance for Developing Member Countries. Asian Development Bank. www.adb.org

Binsar, A. 2013. Faktor-faktor yang mempengaruhi ketepatan waktu penyampaian laporan keuangan kementerian Negara / UAKPA (Studi Kasus pada satu kerja di wilayah kerja KPPN Malang). Skripsi Fakultas Ekonomi dan Bisnis Brawijaya Malang.

Christensen, M. 2002. Accrual accounting in the public sector: the case of the New South Wales government. Article, Accounting History Http://ach.sagepub.com

Damanik, 2011. Faktor-faktor yang Menjadi Kendala Penerapan Standar Akuntansi Pemerintahan (SAP) pada Kota Binjai. Skripsi Fakultas Ekonomi Universitas 
Sumatera Utara. Http/ Respostory/ Usu.ac.id/ hanle/123456789/25663. Diakses 23 Juli 2015.

Dora. S. 2014. Analisis kesiapan Pemerintah dalam menerapkan Standar Akuntansi Pemerintah berbasis Akrual (Studi Kasus Pada BPKD Kota Medan). Skripsi Fakultas Ekonomi Universitas HKBP Nommensen Medan. Di downloadtanggal 10 Januari 2016.

Fadlan, M. 2013. Kesiapan Penerapan PP Nomor 71 Tahun 2010 tentang Standar Akuntansi Pemerintahan pada Laporan Keuangan Pemerintah Daerah Kabupaten Aceh Tengah. Tesis Fakultas Ekonomi dan Bisnis Universitas Gajah Mada

Ghozali, I. 2011. Aplikasi Analisis Multivariate dengan Program IBM SPSS 19 Badan Penerbit Universitas Diponegoro ISBN 979.704.015.1: Semarang.

Halen, Dian, dan Astuti, D. 2013. Pengaruh Tingkat Pemahaman, Pelatihan dan Pendampingan Aparatur Pemerintah Daerah Terhadap Penerapan Accrual Basis Dalam Pengelolaan Keuangan Daerah di Kabupaten Jember. (Studi Kasus Pada Dinas Pemerintahan Kabupaten Jember), Jurnal Ekonomi - Mandala Jember.

Hepworth .N. 2003.Preconditions for Successful Implementation of Accrual Accounting in Central Government. Article Public Money \& Management. Diakses 23 Juli 2015.

Kambanei, T. 2014. Management Accounting and Control System in the Context of Public sector reforms: A case study of $A$ government Department in Papua New Guinea. A thesis submitted in fulfillment of the requirements of the degree of Doctor of business Administration from the University of Canberra, Faculty of Business Government \& Law.

Kusuma, M.I.Y., 2013. Analisis Faktor-faktor yang Mempengaruhi Tingkat Penerapan Akuntansi Akrual pada Pemerintah Daerah; Studi pada satuan kerja KPPN Semarang I. Diponegoro Jurnal of Accounting. Volume2, Nomor 3 Tahun 2013, Halaman ISSN (Online):2337-3806

Kusuma, R.S. 2013. Analisis Kesiapan Pemerintah Daerah Dalam Penerapan Standar Akuntansi Pemerintah Berbasis Akrual (Studi pada Pemerintah Daerah Kabupaten Jember). Skripsi Fakultas Ekonomi Universitas Jember
Lobo, N. A. 2008. Proses Pendampingan Artikel- FISIP Universitas Indonesia. http://www.google.com. Juli 2015

Mardiasmo, 2004. Otonomi \& Manajemen Keuangan Daerah, Penerbit AndiYogyakarta

Mongoloi, R.S. 2013. Analisis Kesiapan Penerapan Akuntansi Berbasis Akrual Pada Biro Keuangan (Kementerian kelautan dan Perikanan). Skripsi Fakultas Ekonomi Universitas Indonesia

Noch, M. Y, 2006. Komitmen Organisasi dan Asimetri Informasi sebagai Pemoderasi Pengaruh Partisipasi Anggaran terhadap Senjangan Anggaran: Studi Empiris pada Dinas Kesehatan Kota dan Kabupaten Jayapura serta kabupaten Keerom. Tesis Fakultas Ekonomi dan Bisnis Universitas Brawijaya Malang.

Nugraheni, P., dan Subaweh,I. 2009. Pengaruh Penerapan Standar Akuntansi Pemerintahan terhadap Kualitas Laporan Keuangan. Jurnal Ekonomi dan Bisnis No. 1 Vol.13 April 2008

Peraturan Menteri Dalam Negeri Republik Indonesia Nomor 64 Tahun 2013,.Penerapan Standar Akuntansi Pemerintah Berbasis Akrual Pada Pemerintah Daerah, cetakan 2014 Penerbit Fokus media Bandung

Peraturan Pemerintah Republik Indonesia Nomor 71 Tahun 2010 tentang Standar Akuntansi Pemerintah, cetak 2013 Penerbit Fokusindo Mandiri Bandung

Pramadani. A. B. dan Fajrianthi. 2012. Hubungan Antara Komitmen Organisasi Dengan Kesiapan Untuk Berubah Pada Karyawan Divisi Enterprise Service (DES) Telkom Ketintang Surabaya. Jurnal Psikologi Industri dan Organisasi. Vol. 1 No. 02, Juni 2012

Pratiwi, P.A.S.A., Musmini, L.S., dan Sujana,E. 2013. Pengaruh Pengetahuan Pengelolaan Keuangan Daerah, Personal Background, dan Komitmen Terhadap Kemampuan Satuan Kerja Perangkat Daerah dalam Penyusunan Laporan Keuangan Daerah.eJournal SI Universitas Pendidikan Ganesaha, Volume 2 No.1 Tahun 2014.

Ranuba, E.D.S., Pangemanan, S., dan Pinatik, S. 2014. Analisis Kesiapan Penerapan SAP Basis Akrual PP.No.71 Tahun 2010 pada DPKPA Minahasa Selatan. Jurnal EMBA.Vol.3 No.1, Maret 2015 (3888-397) ISSN 2303-1174. Diakses 23 Juli 2015 
Sampel, I.F., Kalangi,L., dan Runtu,T. 2014. Analisis Kesiapan Penerapan SAP Basis Akrual PP.No.71 Tahun 2010 pada Pemerintah Kota Menado. Jurnal EMBA.Vol.3 No.1, Maret 2015 (3888-397) ISSN 2303-1174. Diakses 23 Juli 2015.

Sitepu, M.T. 2008. Analisis Faktor-faktor yang Mempengaruhi Penerapan Permendagri No.13 Tahun 2006 (Studi kasus pada Pemerintah Kabupaten Deli Serdang). Skripsi Fakultas Ekonomi Universitas Sumatera Utara

Sugiyono. 2014. Metode Penelitian Kuantitatif, Kualitatif dan $R \& D$. Penerbit Alfabeta, Bandung

Sukadana. I.C., dan Mimba.N.P.S.H. 2015. Pengaruh Kualitas Sumber Daya Manusia Terhadap Kesiapan Penerapan SAP Berbasis Akrual Pada Satuan Kerja Di Wilaya kerja KPPN Denpasar. E- Jurnal Akuntansi Universitas Udayana 12. 1: 4549 ISSN. 2302- 8556. Di download tanggal 10 Januari 2016.

Wibowo, 2014.Manajemen Kinerja, Edisi Keempat, Rajawali Pers Jakarta

Winidyaningrum, C. 2009. Pengaruh Sumber Daya Manusia dan Pemanfaatan Teknologi Informasi Terhadap Keterandalan dan Ketepatan waktu Pelaporan Keuangan Pemerintah Daerah dengan Variabel Intervening Pengendalian Interen Akuntansi. (Studi empiris pada pemda Subosukawonosraten). Tesis Fakultas Ekonomi Program Studi Magister Akuntansi Universitas Sebelas Maret Surakarta.

Winne, A. 2000.Is the Move to Accrual based accounting a real Priority for Public Sector Accounting?

.ACCA. www.accaglobal.com

Yudiaatmaja, F. 2013. Analisis Regresi dengan Menggunakan Aplikasi Komputer Statistik SPSS .Penerbit PT. Gramedia Pustaka Utama, Jakarta 